\title{
Insulin-like growth factor II is an experimental stress inducible gene in a porcine model of brief coronary occlusions
}

\author{
Angelika Kluge, René Zimmermann, Brigitte Münkel, Pieter D Verdouw, Jutta Schaper, \\ and Wolfgang Schaper
}

\begin{abstract}
Objective: Previous observations have shown that myocardium activates many adaptive processes after brief ischaemia. The aim of this study was to determine whether insulin-like growth factors (IGF) as well as their receptors and binding proteins (IGFBP), which control the activity of the IGF, may play an important role during these processes. Methods: Ischaemia was induced in anaesthetised open chest pigs by two 10 min occlusions of the left anterior descending coronary artery, separated by $30 \mathrm{~min}$ of reperfusion, and followed by reperfusion up to $210 \mathrm{~min}$. Tissue from the ischaemic area and from a non-ischaemic control region of the same heart was examined by means of northern blot, slot blot, and in situ hybridisation. Results: IGF-I, IGF-II, the type I receptor, the insulin receptor, and IGFBP-2-6 are constitutively expressed in porcine myocardium. In situ hybridisation showed that IGF-I and IGF-II are mainly transcribed by myocytes. Ischacmia/reperfusion led to an early and significant increase in IGF-II mRNA compared to non-sham controls but not in comparison with sham operated animals, which already showed a (not significantly) enhanced IGF-II expression. In each case the IGF-II mRNA levels are equal in the control and the experimental region of the same heart. Whereas IGF-II expression was already increased by experimental stress, IGFBP-5 mRNA was enhanced only by ischaemia/ reperfusion. The expression of IGF-I, the receptors, and IGFBP-2, 3, 4, and 6 remained unchanged during the experimental protocol. IGFBP-1 was neither expressed nor induced in our model. Conclusions: IGF-II acts like a stress-response gene activated by the experimental conditions (surgery, anaesthesia) and remains induced during following episodes of ischaemia/reperfusion. A possible interaction of IGFBP-5 with other components of the IGF system may contribute to the preconditioning response.
\end{abstract}

Cardiovascular Research 1995;29:708-716

$\mathrm{B}$ rief coronary occlusions result in a prolonged contractile dysfunction and in an increased tolerance of the myocardium against a repeated challenge, a phenomenon that has been termed ischaemic preconditioning.' The mechanisms of these processes are not completely understood. The adaptive changes may occur on the metabolic level but also on the level of translation and transcription, especially in the case of delayed protection. ${ }^{2}$ Repeated short periods of ischaemia and reperfusion, as well as heat stress, cause induction of several heat shock proteins and proto-oncogenes simultaneously with the protection of the heart from subsequent ischaemia/reperfusion injury. ${ }^{34}$ We have shown recently that short periods of ischaemia are powerful regulators of gene transcription, that is, the transcripts of proto-oncogenes and of immediate early genes, ${ }^{5}$ of heat shock protein genes, ${ }^{6}$ of calcium handling protein genes, ${ }^{7}$ of genes regulating blood coagulation and fibrinolysis, and of genes coding for enzymes of the glucose metabolism ${ }^{8}$ are markedly upregulated.

Work in our laboratory has shown that transcripts of peptide growth factors necessary for coronary angiogenesis, like fibroblast growth factor (FGF) and vascular endothelial growth factor (VEGF) are present even in the normal heart where proliferative activity is almost undetectable. ${ }^{9}$ The transcription of VEGF was upregulated after only a few brief occlusions, ${ }^{10}$ which by itself did not lead to increased angiogenic activity. Therefore, based on our own studies, we hypothesised that growth factors may exert trophic functions that are necessary for the survival of cardiac myocytes.

In the present report we show results of a study concerned with the behaviour of insulin-like growth factors (IGF), known as trophic factors for neurones, " in a porcine model of repeated coronary occlusions. IGF-I and IGF-II, which share $62 \%$ amino acid homology ${ }^{12}$ and express several transcripts because of alternate splicing, ${ }^{13}{ }^{14}$ play a central role in regulating growth of mesodermal cells, in differentiation as well as in activating metabolic processses, ${ }^{12}$ and might therefore participate in the adaptive and reparative processes after brief ischaemia. They can bind to specific IGF binding proteins (IGFBP), which are thought to determine their bioavailability and to modulate their biological actions. ${ }^{15}$ For that reason, the gene expression of IGF-I and IGF-II, the six known IGF binding proteins, and the insulin and type-I receptors, which mediate the action of the IGF, was studied in an attempt to determine their potential involvement in adaptive processes after brief ischaemia.

\section{Methods}

All materials for nucleic acid extraction and isolation as wcll as chemicals used for in situ hybridisation were obtained either from Stratagene, Roth, or United States Biochemicals; random primed labelling kits and all reagents for in vitro transcription were purchased from Promega; labelled nucleotides were obtained from Amersham, and Kodak NTB-2 emulsion from Tecnomara. All other reagents and chemiluals were purchased from Merck, Sigma, or Roth. 
Preparation of animals

The experimental protocol described in this study was approved by the animal care committee of the Erasmus University, Rotterdam, The Netherlands. All animals in this study were handled in accordance with the Amcrican Physiological Socicty guidelines for animals welfare and the investigation conformed with the Guide for care and use of laboratory animals published by the US National Institutes of Health.

Seventeen crossbred Landrace $\times$ Yorkshire pigs of either sex (22-40 $\mathrm{kg}$ ) were prepared as previously described. ${ }^{5-7}$ Briefly, after an intravenous injection of $20 \mathrm{mg} \cdot \mathrm{kg}^{-1}$ pentobarbitone sodium and intubation for artificial ventilation with a mixture of oxygen and nitrogen $(1: 2)$, anaesthetised pigs received a $7 \mathrm{~F}$ catheter into the superior caval vein for infusion of $15 \mathrm{mg} \cdot \mathrm{kg}^{-1} \cdot \mathrm{h}^{-1}$ pentobarbitone sodium and pancuronium bromide ( $4 \mathrm{mg}$ ), a 7F Sensodyn micromanometer tipped catheter in the left ventricle for measurement of left ventricular pressure and its first derivative, and an $8 \mathrm{~F}$ catheter in the aorta for measurement of central aortic blood pressure and for collection of blood samples for determination of blood gases. After thoracotomy, the left anterior descending coronary artery was dissected free just distal to its first diagonal branch. Estimation of regional myocardial wall thickening was done as previously published by Brand et al. ${ }^{5}$

After a stabilisation period of at least $30 \mathrm{~min}$, the left anterior descending artery was occluded distal to its first diagonal branch for 10 $\min (n=3)$, followed by $30 \mathrm{~min}$ of reperfusion $(n=3)$, a second period of 10 min occlusion, and a final reperfusion time of $30(n=3), 90$ $(\mathrm{n}=3), 120(\mathrm{n}=2)$, or $210 \mathrm{~min}(\mathrm{n}=4)$. The animals were then killed, the hearts were excised, and tissue samples were collected from the experimental ischaemic region and from the control circumflex coronary artery region, snap frozen in liquid nitrogen, and stored at $-80^{\circ} \mathrm{C}$ until further use. Thus for each animal results from the experimental region could be compared to those in the control area.

Six animals were sham operated to assess the effect of the surgical procedures on induction of myocardial gene expression in the left anterior descending and circumtlex coronary artery regions by exposing the pigs to $80(n=4)$ or $440 \min (n=2)$ of normal perfusion after dissection of the left anterior descending artery. Two non-sham controls were also prepared. These animals were anaesthetised with pentobarbitone sodium as described above and afterwards killed by an overdose of pentobarbitone sodium and by an intravenous injection of $20 \%$ potassium chloride. One slaughterhouse pig served as an additional control. Tissue from different organs of a non-sham control pig was collected, snap frozen in liquid nitrogen, and stored at $-80^{\circ} \mathrm{C}$.

\section{Molecular probes}

The murine $18 \mathrm{~S}$ ribosomal $\mathrm{RN} \Lambda \mathrm{cDNA}$ probe was a generous gift of Dr I Oberbäumer ${ }^{16}$ The probes for human IGF-I, human IGF-II, human insulin receptor, and human type-I receptor were purchased from ATCC. The probe for human IGГВP-1 was kindly placed at our disposal by Dr A G P Schuller ${ }^{17}$ that for ovine IGFBP-2 by Dr V K $\mathrm{M}$ Han, ${ }^{18}$ that for porcine IGFBP-3 by S Shimasaki, ${ }^{19}$ and those for human IGFBP-4-6 by Dr M C Kiefer (Chiron Cooperation, Emeryville, USA). ${ }^{20}{ }^{21}$ In situ hybridisation of IGF-I and IGF-II required subcloning of restriction fragments of these cDNAs in pGEM (Promega) and in $\mathrm{pB}$ luescript (Stratagene), respectively, to generate templates for in vitro transcription. In particular, a 420 bp PstI-BamHI subclone of IGF-I and a 460 bp EcoRI-SalI subclone of IGF-II, both encoding mainly the coding region of each factor, were used. Insert orientation was confirmed by restriction enzyme digestion and automatic sequencing using an ALF DNA sequencer (Pharmacia) and fluorescent T3 and T7 primers (a gift from Pharmacia) according to the manufacturer's protocol.

For northern hlot analysis, cDNA prohes were random primed labelled to a specific activity of about $10^{8} \mathrm{cpm} \cdot \mu \mathrm{g}^{-1}$ using the Primea-gene labelling kit (Promega) and $40 \mu \mathrm{Ci}$ of $\left[\alpha-{ }^{32} \mathrm{P}\right] \mathrm{dCTP}(3000$ Ci.mmol ${ }^{-1}$ ). The IGF-I probe was either a 659 bp PstI fragment, corresponding to the entire insert as purchased from ATCC, or a 420 bp Pst I-BamHI fragment as used for in situ hybridisation. Both probes showed the same signals in northern blot analysis. The same was true for the IGF-II probes, a $1.0 \mathrm{~kb} E c o$ RI fragment (ATCC) or a $460 \mathrm{bp}$ $E c o$ RI-Sall fragment. The IGF-I and IGF-II probes showed no cross hybridisation and detect signals specific for each factor. The IGFBP-1 probe was an $E c o$ RI insert of $1.2 \mathrm{~kb}$, the IGFBP-2 probe a $690 \mathrm{bp} A c c \mathrm{I}-$ Sphl fragment, the IGFBP-3 probe a 600 bp EcoRI-SmaI insert, the IGFBP-4 probe an 800 bp HindIII-EcoRI fragment, the IGFBP-5 probe a 660 bp EcoRI-PstI insert, and the IGFBP-6 probe a 980 bp EcoRI fragment. For the insulin receptor a $900 \mathrm{bp} E c o \mathrm{RI}$ fragment and for the type-I receptor a 520 bp EcoRl-Pvull insert was used. The I8S cDNA probe was a $770 \mathrm{bp}$ EcoRI-BamHI fragment.

For in situ hybridisations of IGF-I and IGF-II, in vitro transcription techniques were used. First $1 \mu \mathrm{g}$ of cDNA, linearised with the appropriate restriction enzyme, was transcribed using T3 RNApolymerase T7 RNA-polymerase, or SP6 RNA-polymerase, and 100 $\mu \mathrm{Ci}$ of $\left[\alpha-{ }^{3} \mathrm{~S}\right] \mathrm{UTP}\left(1000 \mathrm{Ci} \cdot \mathrm{mmol}^{-1}\right)$ to generate antisense and sense RNAs. After digestion with RNase-free DNase, labelled RNAs were stored in $0.1 \mathrm{M}$ dithiothreitol (DTT) at $-80^{\circ} \mathrm{C}$. Probe specificity was confirmed by hybridising identical northern blots of total RNA with about $1 \times 10^{6} \mathrm{cpm} \cdot \mathrm{ml}^{-1}$ of freshly synthesised probc and comparing the signals with the ones from ${ }^{32} \mathrm{P}$ hybridised northern blots.

Northem blot and slot blot aralysis

Total RNA from frozen heart tissue was isolated according to the method of Chomczynski and Sacchi. ${ }^{22}$ Fifteen micrograms of total RNA from control and experimental tissue of the same heart were size fractionated as pairs on a $1 \%$ agarose gel containing $0.66 \mathrm{M}$ formaldehyde. The integrity of the RNA was judged under ultraviolet light. After vacuum transfer to a Hybond-N nylon membrane (Amersham) using $10 \times \mathrm{SSC}(1.5 \mathrm{M} \mathrm{NaCl}, 0.15 \mathrm{M}$ sodium citrate, $\mathrm{pH}$ 7.0) as transfer buffer, the fixation of the RNA to the filter followed by means of an ultraviolet crosslinker (Stratagene). Slot blot analysis using $5 \mu \mathrm{g}$ of total RNA was performed as described by Sambrook and coworkers. ${ }^{23}$

Prehybridisation for $4-6 \mathrm{~h}$ at $42^{\circ} \mathrm{C}$ in a buffer containing $50 \%$ deionised formamide, $0.2 \%$ polyvinylpyrollidone, $0.2 \%$ ficoll. $0.2 \%$ hovine serum albumin, $10 \%$ dextran sulphate, $1 \%$ sodium dodecyl sulphate (SDS), $1 \mathrm{M} \mathrm{NaCl}, 50 \mathrm{mM}$ TrisHCl pH 7.5, $0.1 \% \mathrm{Na}_{4} \mathrm{P}_{2} \mathrm{O}_{7}$, and $0.1 \mathrm{mg} \cdot \mathrm{ml}^{-1}$ denatured salmon sperm DNA was followed by hybridisation of the filters for about $16 \mathrm{~h}$ at $42^{\circ} \mathrm{C}$ in the same buffer containing $1 \times 10^{6} \mathrm{cpm} \cdot \mathrm{ml}^{-1}$ of random primed labelled probe. After washing to a final stringency of $0.2 \times \mathrm{SSC} / 0.1 \% \mathrm{SDS}$ at $60^{\circ} \mathrm{C}$ and quantification of the signals, filtcrs wcre exposed at $-80^{\circ} \mathrm{C}$ to X-OMAT AR films (Kodak) using intensifying screens for up to $5 \mathrm{~d}$. Filters were sequentially hybridised with different probes and finally rehybridised with an $18 \mathrm{~S}$ cDNA probe for control purposes. ${ }^{16}$ Additionally, each gel was done at least in duplicate to control for variability within and between gels

\section{Quantification}

After hybridisation, the signals were quantified with a PosphorImager (Molecular Dynamics) using ImageQuant software. For normalisation, the data of each hybridisation signal were divided by the values for the matching $18 \mathrm{~S}$ signal. The average of the data obtained for the left ventricle of non-sham control pigs was standardised at $100 \%$. All data were presented as mean(SEM). Expression was assessed by an unpaired two tailed $t$ test. Statistical significance was accepted at $P<0.05$.

In situ hybridisation analysis

Cryostat sections $(4 \mu \mathrm{m})$ of tissue from the control and the ischaemic heart region was placed on slides coated wtih 3-aminopropyltriethoxysilane (Sigma) and fixed with $4 \%$ paraformaldehyde for 10 min. The slides were washed in distilled water, gradually dehydrated through graded ethanol, dried, and directly used for in situ hybridisation studies. For that purpose, each section was covered without furthe pretreatment with $60 \mu \mathrm{l}$ of hybridisation buffer containing $0.3 \mathrm{M} \mathrm{NaCl}$ $10 \mathrm{mM} \mathrm{Na}_{2} \mathrm{IIPO}_{4}, 10 \mathrm{mM}$ TrisHCl pII 7.5, $5 \mathrm{mM}$ EDTA pH 8.0, 0.02\% polyvinylpyrollidone, $0.02 \%$ ficoll, $0.02 \%$ bovine serum albumin, 750 $\mu \mathrm{g} \cdot \mathrm{ml}^{-1}$ tRNA (yeast or $E$ coli), $0.1 \mathrm{M}$ DTT, $10 \%$ dextran sulphate, $50 \%$ deionised formamide, and about $2.5 \times 10^{6} \mathrm{cpm}$ of denatured antisense RNA probe $(5 \mathrm{ng})$, and hybridised overnight in a humidified chamber at $50^{\circ} \mathrm{C}$.

To control for the specificity of the signals, in all experiments serial sections of the same tissue were hybridised with a labelled RNA probe in the sense orientation as a negative control under identical conditions. Non-specificity of the probe was checked by pretreatment of some sections with $20 \mathrm{mg} \cdot \mathrm{ml}^{-1}$ RNase A (Sigma) before hybridisation in a buffer containing $0.8 \mathrm{M} \mathrm{NaCl}, 10 \mathrm{mM}$ TrisHCl pH 7.5, and $1 \mathrm{mM}$ EDTA pH 7.5 for $1.5 \mathrm{~h}$, followed by two washes in a buffer containing $0.1 \mathrm{M}$ TrisHCl pH 7.5, $0.1 \mathrm{M} \mathrm{NaCl}$, and $2 \mathrm{mg} \cdot \mathrm{ml}^{-1}$ glycine for $5 \mathrm{~min}$ each.

After hybridisation, sections were washed three times for $1 \mathrm{~h}$ each at $50^{\circ} \mathrm{C}$ in a buffer containing $50 \%$ deionised formamide, $0.3 \mathrm{M} \mathrm{NaCl}$ $10 \mathrm{mM} \mathrm{Na}{ }_{2} \mathrm{HPO}_{4}, 10 \mathrm{mM}$ TrisHCl pH 7.5, $5 \mathrm{mM}$ EDTA pH 8.0, $0.02 \%$ polyvinylpyrollidone, $0.02 \%$ ficoll, $0.02 \%$ bovine serum albumin, and $1 \mathrm{M}$ DTT Slides were then rinsed five times in RNase buffer $(0.5 \mathrm{M}$ $\mathrm{NaCl}, 10 \mathrm{mM}$ TrisHCl pH 7.5, $1 \mathrm{mM}$ EDTA pH 8.0, $1 \mathrm{mM}$ DTT) and incubated in the same buffer containing RNase $\mathrm{A}\left(150 \mu \mathrm{g} \cdot \mathrm{ml}^{-1}\right)$ for $1 \mathrm{~h}$ at $37^{\circ} \mathrm{C}$ to reduce background. After final washes at $65^{\circ} \mathrm{C}$ in $2 \times$ SSC with $1 \mathrm{mM}$ DTT twice and once at $42^{\circ} \mathrm{C}$ in $0.1 \times \mathrm{SSC}$ with $1 \mathrm{mM}$ DTT for $1 \mathrm{~h}$ each, sections were dehydrated and exposed to Kodak NTB-2 emulsion for 8-16 d. Finally, sections were counterstained with $0.1 \%$ toluidine blue and used for brightfield and darkfield microscopy.

\section{Results}

Expression of IGF-II in normal and ischaemic myocardium By using northern hybridisation in pig hearts subjected to the occlusion/reperfusion protocol we observed several species of IGF-II mRNA $(1.7,1.9,2.8,4.8$, and $6.0 \mathrm{~kb}$; figs 1,2$)$. 


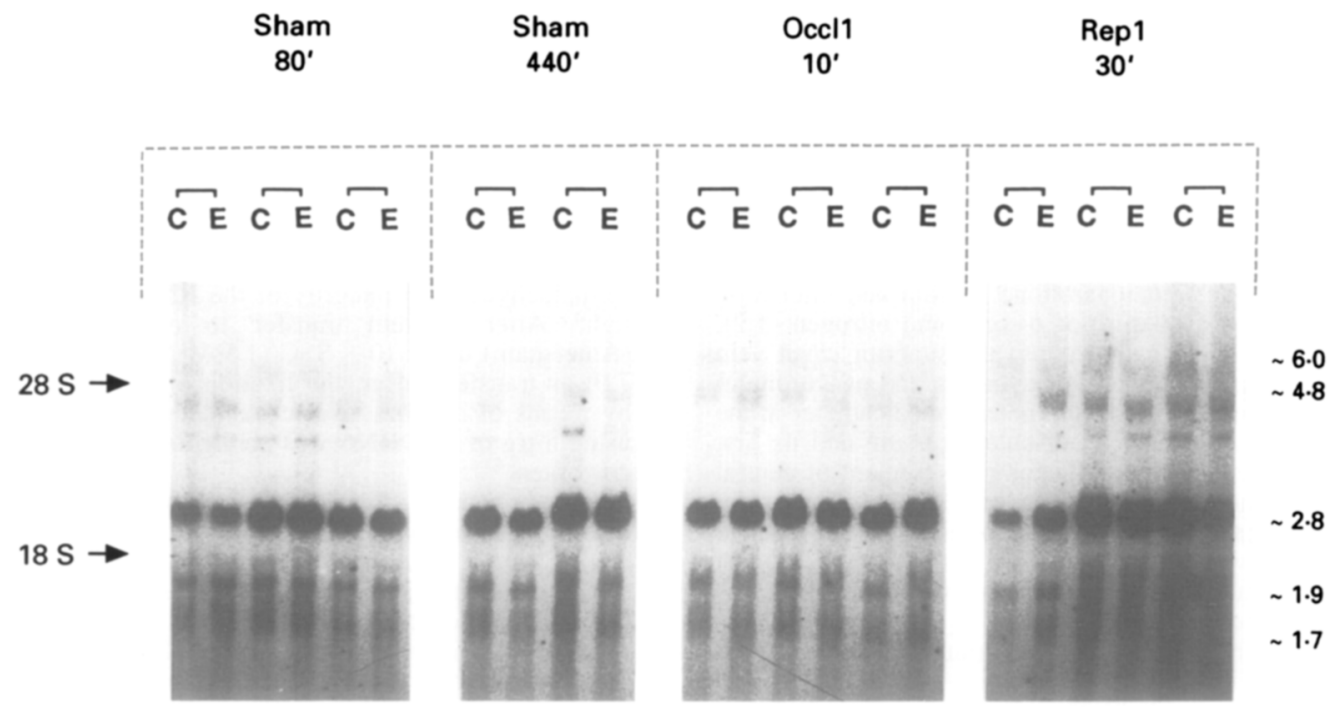

$18 \mathrm{~S} \rightarrow$

Figure 1 Northern blot analysis showing the first part of myocardial IGF-II mRNA expression in the repeated occlusion model in pigs. Sham operated animals were subjected to $80 \mathrm{~min}$ (sham $80^{\prime}$ ) or $440 \mathrm{~min}$ (sham 440') of normal perfusion. The left anterior descending

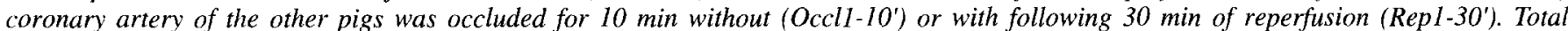
RNA samples from the control region $(C)$ as well as the experimental ischaemic area $(E)$ of the same heart were loaded as pairs. For control purposes, the blot was also hybridised with an $18 S$ cDNA probe as shown in the lower panel. The approximate size of the mRNA bands is expressed in kilobases. The positions of $18 S$ and $28 S$ rRNA are indicated

In sham operated pigs IGF-II mRNA levels were independent of the duration of the experiment because IGF-II mRNA was similarly expressed at 80 or $440 \mathrm{~min}$ of normal perfusion after thoracotomy and preparation of the left anterior descending coronary artery (fig 1). A single $10 \mathrm{~min}$ occlusion as well as a subsequent reperfusion period of 30 min revealed no effect on IGF-II gene expression in comparison with the sham operated pigs. Unexpectedly, the sham operated pigs already expressed an enhanced IGF-II mRNA level in both regions studied in comparison with a slaughterhouse pig (fig 2) as additional control, which was characterised by a much less intense myocardial expression of IGF-II mRNA. Furthermore, after a second occlusion followed by $30,90,120$, or 210 min of reperfusion an IGF-II mRNA level similar to that of the sham operated animals was expressed. At every time point studied the IGF-II mRNA concentration was equal in the control and experimental area of the same heart.

Since densitometry of five different bands per filter is cumbersome and inaccurate, quantification of IGF-II mRNA
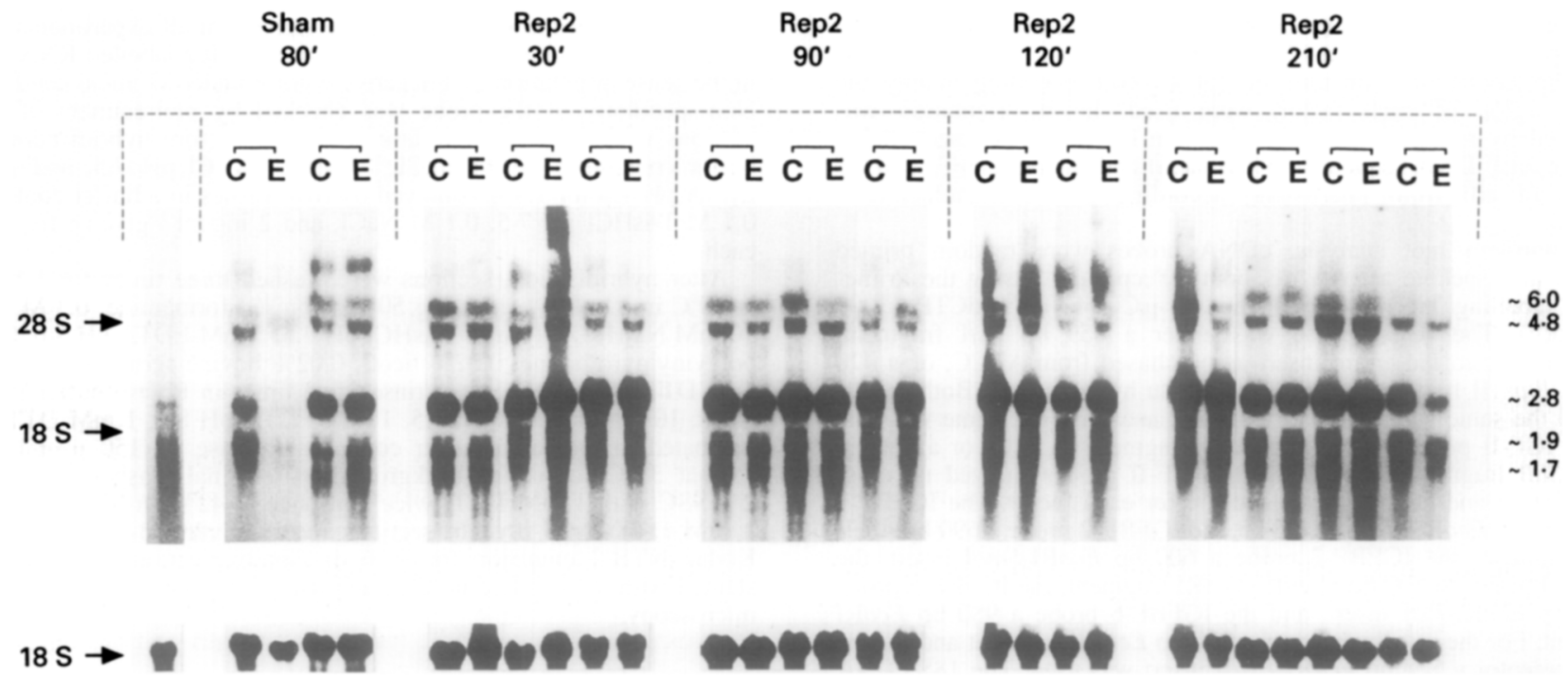

Figure 2 Northern blot hybridisation showing the second part of IGF-II mRNA expression after repeated occlusions in porcine hearts. Total RNA from the control region $(C)$ as well as the experimental ischaemic area $(E)$ of the same hearts were electrophoresed as pairs. In the first lane total RNA extracted from a heart of a slaughterhouse pig was loaded. Sham operated animals were subjected to 80 min (sham 80') of normal perfusion. The left anterior descending coronary artery of the other pigs was occluded twice for 10 min, separated

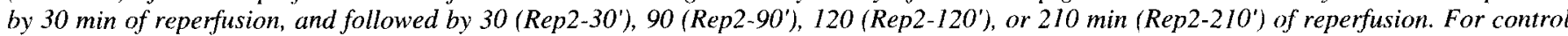
purposes, the blot was also hybridised with an $18 S$ cDNA probe as shown in the lower panel. The approximate size of the mRNA bands is expressed in kilobases. The positions of 185 and $28 S$ rRNA are indicated. 


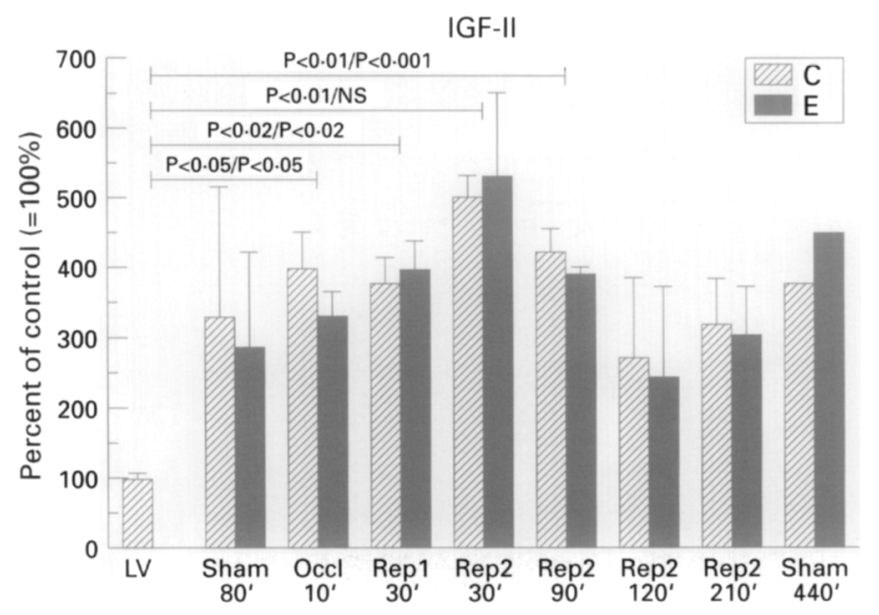

Figure 3 Bar graph showing IGF-II mRNA expression during the cycle described in figs 1 and 2 . Quantification of the IGF-II mRNA levels was performed by means of slot blot analysis. Changes in the experimental ischaemic/reperfused (hlack hars) and normal perfused control heart region (hatched bars) are shown. Data are means, error bars $=S E M$. The average of the values obtained for the left ventricle (LV) of non-sham control pigs was standardised at $100 \%$. Levels of significance are shown for control and experimental heart tissue, respectively.

expression was performed by means of slot blot analysis (fig 3) which was available for two sham operations at $80 \mathrm{~min}$ (out of four), one $440 \mathrm{~min}$ sham operated animal (out of two), and for all ischaemic/reperfused hearts with the exception of the Rep2-210' group (three out of four). The IGF-II gene expression in two non-sham control hearts was also studied. These data revealed that the sham operation itself markedly enhanced the IGF-II mRNA level (though this was not statistically significant versus non-sham controls). A single 10 min occlusion had no influence on IGF-II gene expression in comparison with the sham operated pigs but was significantly different from non-sham control, as were the following ischaemic/reperfused groups including Rep2-90'. The two late reperfusion groups showed no statistical difference from non-sham control animals. The main finding of our experiments, based on visual inspection of northern blots and quantitative data from slot blots, is that stress due to the experimental conditions (surgery and anaesthesia) markedly increased IGF-II gene expression in left ventricular myocardium in both regions studied and that this raised level was perhaps somewhat modified during subsequent occlusion/reperfusion periods, that is, expression seems to increase slightly during the early time course studied and to decrease late in reperfusion whereas values obtained late in sham operated animals seem to remain high (statistically not significant).

To evaluate IGF-II gene expression in normal porcine organs we studicd the mRNA levels in several different tissues. IGF-II was expressed constitutively in all porcine organs, except small intestine (fig 4). The highest IGF-II mRNA level was seen in skeletal muscle, followed by heart, spleen, kidney, lung, and liver. However, only in porcine hearts with raised IGF-II mRNA levels, that is, in hearts subjected to sham operation or to repeated coronary occlusions, could a $6.0 \mathrm{~kb}$ transcript clearly be detected which was not visible in the other organs and in the myocardium of non-sham control pigs. It is not known whether the $6.0 \mathrm{~kb}$ mRNA is specific for the ischaemic heart, that is, whether it can be seen in other tissues subjected to ischaemia/reperfusion. Liver expressed a band of $5.3 \mathrm{~kb}$ besides additional transcripts of 1.7 and $1.9 \mathrm{~kb}$.

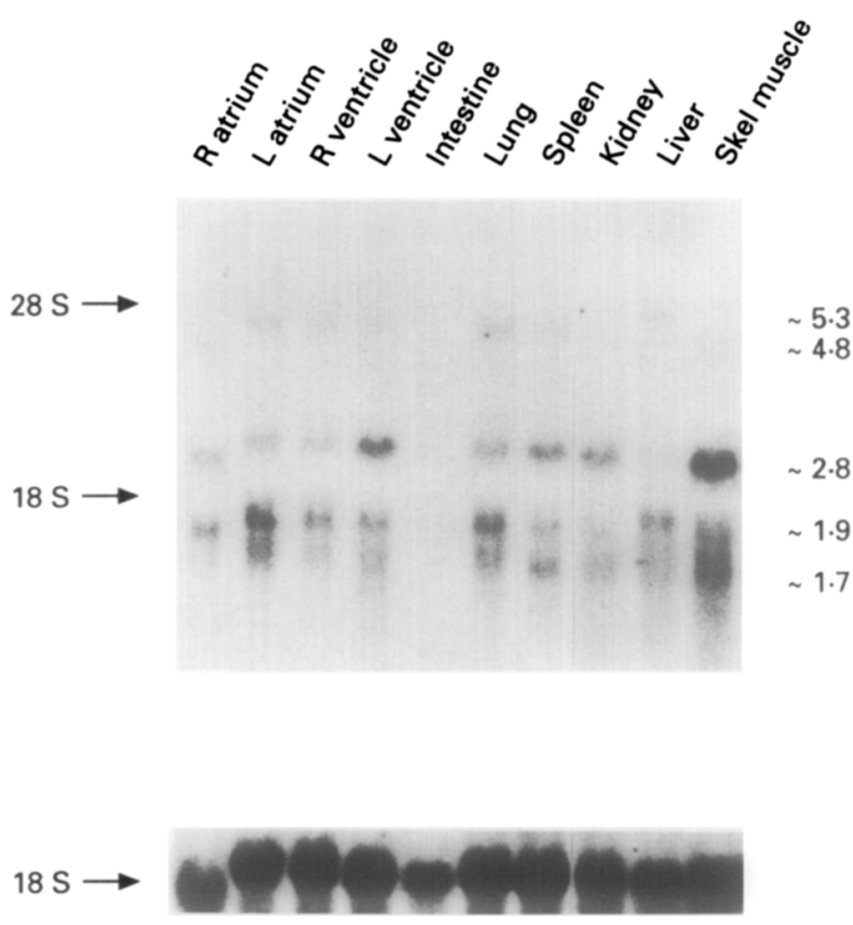

Figure 4 Northern blot analysis showing the expression of IGF-II $m R N A$ in different organs of a non-sham control pig. For the control of mRNA loading the $18 S$ rRNA hybridisation is shown in the lower panel. The approximate size of the mRNA bands is expressed in kilobases. The positions of $18 \mathrm{~S}$ and $28 \mathrm{~S}$ rRNA are indicated. $R=$ right $L=$ left.

In situ hybridisation studies identified the myocytes as the main producers of IGF-II mRNA in porcine heart (fig $5 \mathrm{~A}$, B). Fibroblasts of the interstitium were also labelled. Microscopic studies revealed a similar amount of cells transcribing IGF-II in the control and experimental region of the same heart. No difference in the extent of labelled cells in sham operated hearts and in myocardium subjected to the experimental protocol was observed. Very rarely endothelial cells and smooth muscle cells of blood vessels showed a signal (data not shown).

\section{IGF-I gene expression in ischaemic heart}

In porcine myocardium we identified IGF-I mRNAs of 1.0 and $7.6 \mathrm{~kb}$ (fig 6A). Repeated coronary occlusions did not change the expression of IGF-I mRNA, either after the first or after the second occlusion followed by various times of reperfusion. In each case, the IGF-I mRNA showed comparable levels in the control and ischaemic region of the same heart. The IGF-I mRNA level of the sham operated pigs were not enhanced compared to the non-sham controls. This indicates that IGF-I is constitutively expressed in myocardium and that its expression is insensitive to brief ischaemic periods and to other experimental stresses.

In situ hybridisation studies showed that IGF-I is mainly transcribed by myocytes in the control myocardium as well as in the myocardium subjected to brief repeated occlusions (fig 7A, B). Some fibroblasts of the interstitium also expressed IGF-I mRNA. Vascular smooth muscle cells were rarely labelled (data not shown).

\section{Expression of IGF binding proteins and receptors after} brief coronary occlusions

With the exception of IGFBP-1, northern blot analysis revealed constitutive mRNA expression of IGFBP-2-6 in normal heart (figs 6B and 8). All studied IGFBP showed a 

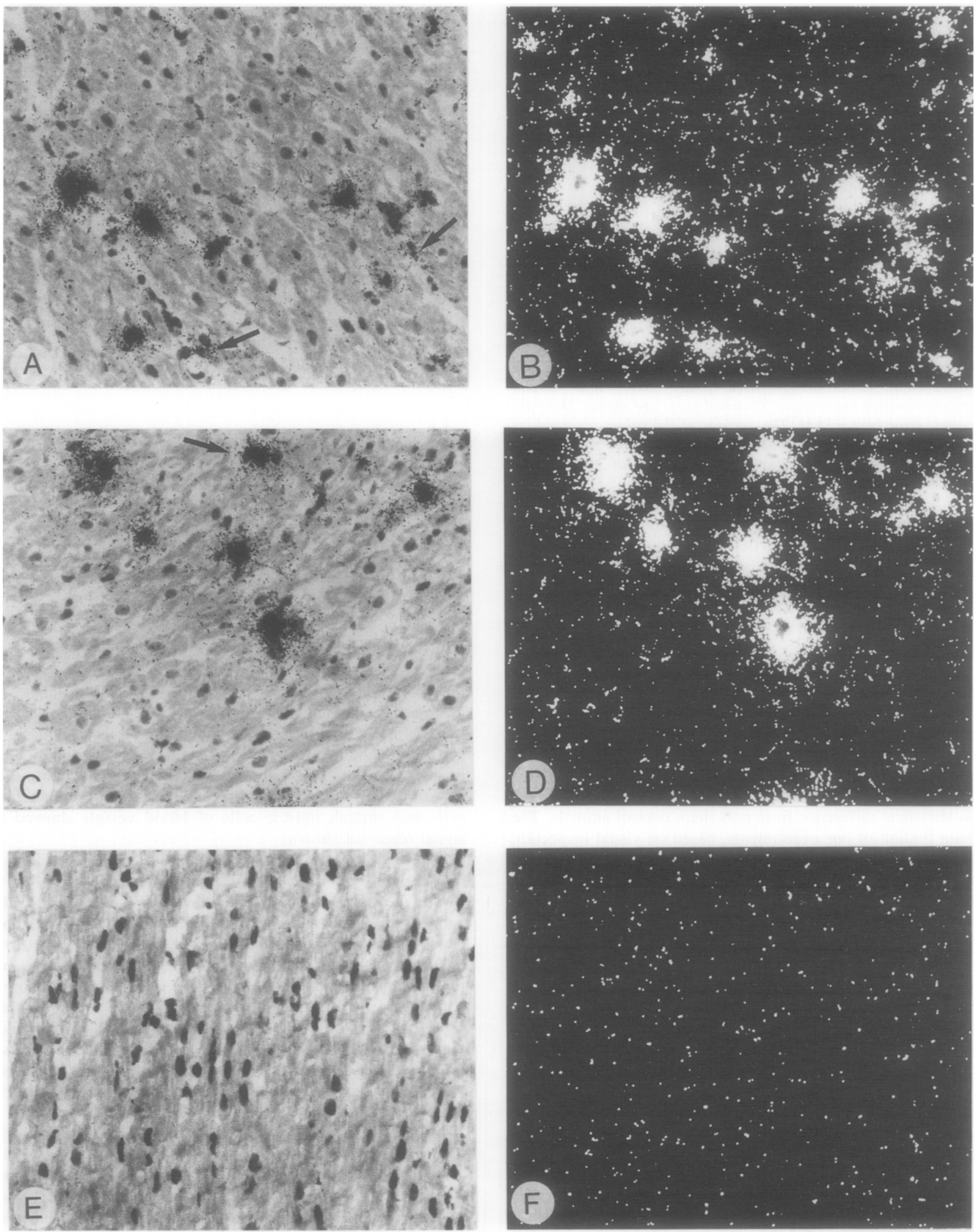

Figure 5 In situ hybridisation of IGF-II mRNA in porcine myocardium. Toluidine blue stained sections are shown on the left and the corresponding darkfield microphotographies on the right. In the myocardium subjected to ischaemia/reperfusion episodes $(A, B)$ as well as in the control areas of the same heart $(C, D)$ the myocytes are the main producers of IGF-II mRNA. To a lesser extent IGF.II is transcribed by fibroblasts (arrows) in the interstitium. Panel $E$ and $F$ show the control hybridisation of ischaemic cardiac tissue with IGF-II sense RNA probe. (Magnification: 240 $\times$.) 
single transcript, for example, IGFBP-2 showed a band of $2.0 \mathrm{~kb}$, IGFBP-3 a $2.6 \mathrm{~kb}$ mRNA, IGFBP-4 a transcript of $2.3 \mathrm{~kb}$, IGFBP-5 a band of $6.0 \mathrm{~kb}$, and IGFBP-6 a $1.3 \mathrm{~kb}$ mRNA, as previously described. ${ }^{24}$ The gene expression of IGFBP-3, IGFBP-4, and IGFBP-6 remained unaltered after brief coronary occlusions. Concerning IGFBP-2 we observed increases following ischaemia and experimental stress but, because of the marked variability in gene expression between the animals studied, statistical significance was not reached (fig 8A). IGFBP-5 mRNA expression was significantly increased at Rep1-30 in the control as well as in the

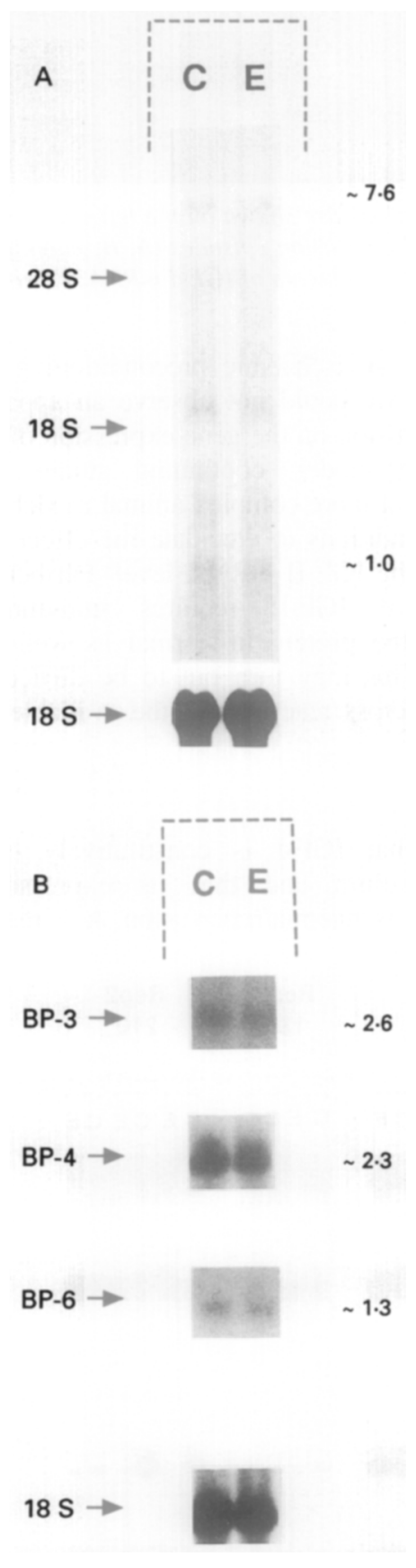

Figure 6 Northern blot analysis showing the expression of IGF-I (panel A), or IGFBP-3, IGFBP-4, and IGFBP-6 (panel B) mRNA in the control $(C)$ and in the experimental $(E)$ region of one porcine heart subjected to brief repeated occlusions as a representative for the unaffected, constant level of transcripts in the animal model studied. For control of mRNA loading the 18S rRNA hybridisation is shown in the lower panel. The approximate size of the $m R N A$ bands is expressed in kilobases. The positions of 185 and $28 S \mathrm{rRNA}$ are indicated. experimental region of the same heart in comparison with the non-sham control animals, but experimental stress had no effect (figs 8B and 9). The insulin receptor and the type-I receptor were constitutively transcribed in porcine myocardium and their gene expression remained insensitive towards the experimental protocol (data not shown).

\section{Discussion}

Properties and functions of IGF-II

In our experiments, transcription of porcine IGF-II gene results in five mRNA species, which were most probably derived by alternate processing as reported for the human gene. $^{14}$ The size of porcine IGF-II mRNAs showed a species specific divergence, as described for human ${ }^{14}$ and bovine tissues. ${ }^{25}$ We also found a transcript specific for adult pig liver with a size of $5.3 \mathrm{~kb}$, probably due to the activation of a different promoter as reported for human or bovine adult liver. ${ }^{1425}$ In pigs hearts subjected to sham operation or to brief repeated occlusions an $\mathrm{KGH}-\mathrm{Il}$ transcript of $6.0 \mathrm{~kb}$ appeared, which may represent an alternatively spliced form of the gene. The $6.0 \mathrm{~kb}$ species was not present in skeletal muscle, which otherwise strongly expresses IGF-II mRNA, or in any other organ tested. Since we have not looked at the expression of this mRNA species in other organs subjected to ischaemia we have no evidence if it is ischaemia specific or heart specific, or both. Moreover, this transcript may be expressed constitutively at a level below detection with northern hybridisation.

Neonatal rat myocytes, ${ }^{26}$ and endothelial, ${ }^{27}$ smooth muscle cells, ${ }^{28}$ as well as fibroblasts ${ }^{29}$ are known to transcribe IGFII, and we show here that in fact all these cell types, but mainly cardiac myocytes, constitutively synthesise IGF-II mRNA in adult porcine heart in vivo. Even though IGF-II is a mitogen for different cell types, ${ }^{30}$ it seems to exert mainly non-mitogenic physiological functions in normal myocardium because cell proliferation is almost undetectable in the normal heart. IGF-II may be involved in the maintenance of basic functions of myocytes by performing its insulin-like metabolic effects or by acting as a positive inotropic agent. ${ }^{30}$ The action of IGF-II seems to be mediated through the type-I receptor and the insulin receptor, which are known to bind IGF-II with high and low affinity, respectively, ${ }^{12}$ and which are both constitutively transcribed in our model.

IGF-II acts like a sensitive stress response gene During the course of our studies with IGF-II it became apparent that hearts can be grouped into three classes: nonsham controls (normal hearts quickly excised under general anaesthesia) had the lowest levels; sham operated hearts (thorax opened under general anaesthesia and left open with artificial ventilation for 80 to $440 \mathrm{~min}$, coronaries prepared but not occluded) had increased levels; and hearts with the full occlusion/reperfusion protocol, in which the IGF-II mRNA level was increased to more or less the same extent as was observed for the second group. We conclude that IGFII was already activated by the sham operation (an interesting trend but statistically not significant) and that the enhanced IGF-II mRNA levels of porcine hearts subjected to periods of ischaemia and reperfusion are most probably due to the prior andesthesia followed by thoracotomy and preparation of the coronary artery and are not necessarily specific for ischaemia. Interestingly, in no group with raised IGF-II mRNA concen trations was there a difference between the experimental and the control region of the same heart. 

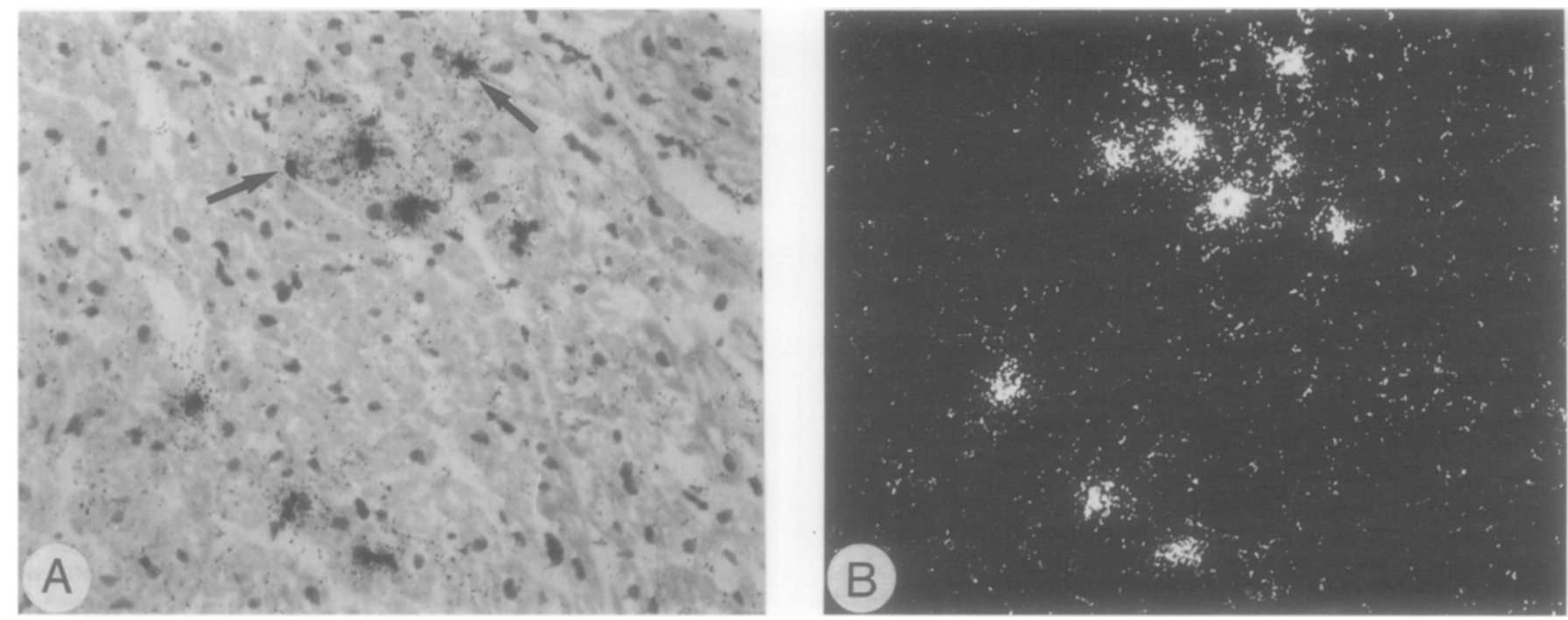

Figure 7 In situ hybridisation of IGF-I mRNA in porcine heart. Toluidine blue stained sections are shown on the left and the corresponding darkfield microphotographies on the right side. In the myocardium subjected to ischaemia/reperfusion episodes (A, B; magnification: 250 $\times$ ) as well as in the control areas of the same heart (data not shown) the myocytes are the main producers of IGF-I mRNA. Fibroblasts (arrows) in the interstitium transcribe IGF-I to a lesser extent.

The fact that the sham operation itself influences cardiac gene expression was already shown for $c-m y c$ after preparation of the pulmonary artery. ${ }^{31}$ Moreover, Marber and coworkers $^{32}$ found that HSP 72 was upregulated because of thoracotomy, and there was a further enhancement in its expression after repeated coronary occlusions. In common with the functions of several heat shock proteins ${ }^{33}$ IGF-II suppresses protein degradation and its supports protein synthesis and the uptake of amino acids. ${ }^{34}$ It appears possible that IGF-II exerts a protective role in myocardium by aiding the survival of myocytes after damage by stress, in analogy to its trophic functions in the brain, ${ }^{11}$ an organ that is terminally differentiated like the heart. We now have preliminary evidence that IGF-II, when directly infused into pig myocardium, induces a preconditioning response observed one hour after administration (A Vogt, W Schaper, personal communication), that is, in a time somewhat shorter than that needed to elicit an ischaemic preconditioning response (80 minutes). Since we could not observe an apparent effect of ischaemia/reperfusion on the gene expression of IGF-II in our applied porcine model, continuing studies have to be performed using a more complex animal model with different experimental conditions to elucidate the effect of ischaemia/ reperfusion on the IGF-II mRNA level. Further investigation of the role of IGF-II requires immunohistochemical localisation of the protein in normal as well as ischaemic porcine heart. This may turn out to be difficult due to the general lack of cross reactivity of the available antibodies in the pig system. ${ }^{12}$

\section{Other findings}

We observed that IGF-I is constitutively transcribed in porcine myocardium and that its expression remained unaltered during ischaemia/reperfusion. As already shown for

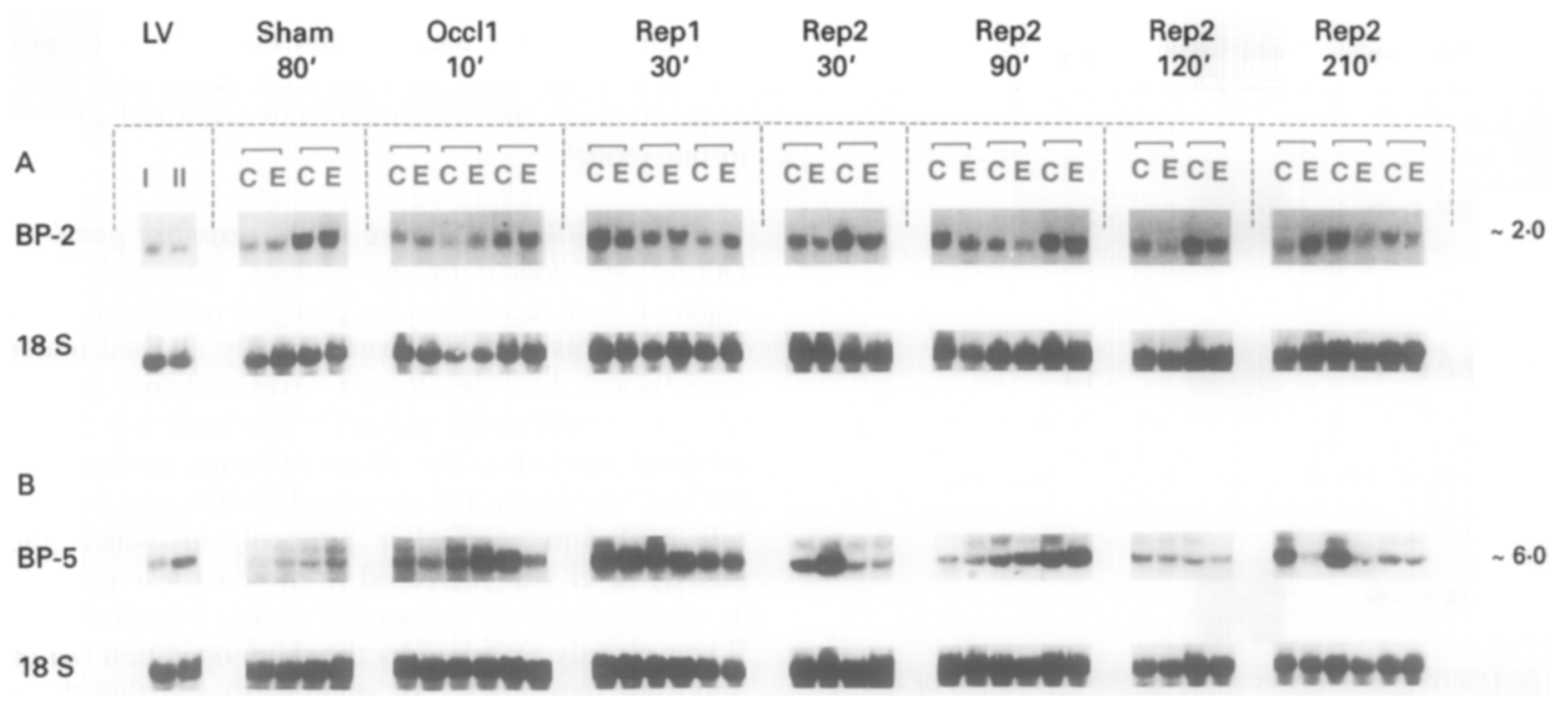

Figure 8 Northern blot analysis showing the gene expression of IGFBP-2 (panel A) and IGFBP-5 (panel B) in the repeated occlusion model in pigs. Total RNA extracted from the left ventricle $(L V)$ of two non-sham control pigs was loaded in the first two lanes. Sham operated animals were subjected to $80 \mathrm{~min}$ (sham 80') of normal perfusion. The left anterior descending coronary artery of the other pigs was occluded once for $10 \mathrm{~min}$ without $\left(\mathrm{Occll}_{1} \mathrm{10}^{\prime}\right)$ or with following $30 \mathrm{~min}$ of reperfusion (Rep1-30') or twice for 10 min, separated by 30 min of reperfusion, and followed by 30 (Rep2-30'), 90 (Rep2-90'), 120 (Rep2-120'), or 210 min (Rep2-210') of reperfusion. Total RNA samples from the control region $(C)$ as well as from the experimental ischaemic area $(E)$ of the same heart were loaded as pairs. For control purposes, the blot was also hybridised with an $18 S$ cDNA probe as shown in the lower panel. The approximate size of the mRNA bands is expressed in kilobases. The positions of 185 and $28 S$ rRNA are indicated. 


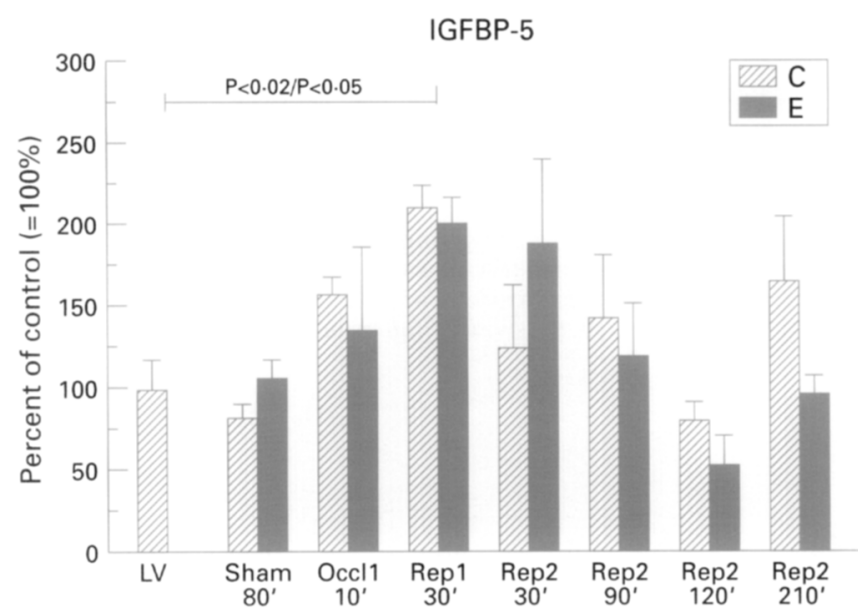

Figure 9 Bar graph showing the gene expression of IGFBP-5 during the cycle described in fig 8 . Changes in the experimental ischaemic/reperfused (black bars) and normal perfused control heart region (hatched bars) are shown. Data are means, error bars $=S E M$. The average of the values obtained for the left ventricle ( $L V$ ) of non-sham control pigs was standardised at $100 \%$. Levels of significance are shown for control and experimental heart tissue, respectively.

IGF-II, the cardiac myocytes are the main producers of IGF-I mRNA, and we believe that IGF-I may also be involved in maintaining basic functions of myocytes where its mitogenic potencies cannot be used for the previously mentioned reasons. We did not measure IGF-I gene expression in different porcine organs because Leaman and coworkers had already shown that pig IGF-I mRNA levels were highest in skeletal muscle, followed by heart and by liver. ${ }^{35}$

The activity of IGF-II is also regulated by the expression of the IGF binding proteins which usually have a higher affinity for the ligand than the receptor. ${ }^{15}$ IGFBP-5 was induced by ischaemia/reperfusion but not by experimental stress, and its peak expression was somewhat later than that of IGF-II. Differential expression of a trophic factor and its binding protein could be the basis of a model of time limited protection as in ischaemic preconditioning, that is, a hypothetical protective effect by a trophic factor could be neutralised by the subsequent upregulation of its binding protein, which would render the organ refractory to repeated stimulation for some time. It can also be hypothesised that a protective effect occurs only when the factor and its binding protein interact. Since IGFBP-5 is upregulated only with ischaemia/reperfusion, ischaemia specificity of the preconditioning response may be explained by the IGF system.

We thank Mrs Claudia Ullmann and Elfriede Neubauer for their outstanding technical assistance. The excellent photographic work of Mrs Annemarie Möbs, as well as the computer work of Dr Bernd Winkler and Mr Gerhard Stämmler are gratefully acknowledged. The work of $\mathrm{AK}$ is presented in partial fulfilment of the requirement for $\mathrm{Dr}$ rer nat (PhD) at the Justus-Liebig-Universität Giessen.

Key terms: ischaemia; gene expression; insulin-like growth factor; insulin-like growth factor hinding protein; porcine heart

Received 6 June 1994; accepted 4 January 1995. Time for primary review 25 days.

1 Schott RJ, Schaper W. Ischemic preconditioning and myocardial stunning: related consequences of brief coronary occlusion and reperfusion? Adv Cardiol 1990;37:32-41.

2 Yellon DM, Latchman DS, Marber MS. Stress proteins - an endogenous route to myocardial protection: fact or fiction? Cardiovasc Res 1993;27:158-61.
3 Das DK, Engelman RM, Kimura Y. Molecular adaptation of cellular defences following preconditioning of the heart by repeated ischaemia. Cardiovasc Res 1993;27:578-84.

4 Yellon DM, Pasini E, Cargnoni A, Marber MS, Latchman DS, Ferrari R. The protective role of heat stress in the ischaemic and reperfused rabbit myocardium. J Mol Cell Cardiol 1992;24: 895-907.

5 Brand T, Sharma HS, Fleischmann KE, Duncker DJ, McFalls EO, Verdouw PD, et al. Proto-oncogene expression in porcine myocardium subjected to ischemia and reperfusion. Circ Res 1992; 71:1351-60.

6 Andres A, Sharma HS, Knöll R, et al. Expression of heat shock proteins in the normal and stunned myocardium. Cardiovasc Res 1993:27:1421-9.

7 Frass O, Sharma HS, Knöll R, et al. Enhanced gene expression of calcium regulatory proteins in porcine stunned myocardium Cardiovasc Res 1993;27:2037-43.

8 Knöll R, Arras M, Zimmermann R, Schaper J, Schaper W. Changes in the gene expression following short coronary occlusions studied in porcine hearts with run-on assays. Cardiovasc Res 1994;28:1062-9.

9 Schaper W, Sharma HS, Zimmermann R, Mohri M, Schaper J. Ischemia-induced angiogenesis (Abstract). $J$ Mol Cell Cardiol 1992;24(suppl I):S.40.

10 Sharma HS, Sassen L, Knöll R, Verdouw PD. Myocardial expression of vascular endothelial growth factor: enhanced transcription during ischemia and reperfusion (Abstract) Circulation 1992;86(suppl I):I-294.

11 Neff NT, Prevette D, Houenou LJ, et al. Insulin-like growth factors - putative muscle-derived agents that promote motoneuron survival. J Neurobiol 1993;24:1578-88.

12 Humbel RE. Insulin-like growth factors I and II. Eur J Biochem 1990;190:445-62

13 Steenbergh PH, Koonen-Reemst AMCB, Cleutjens CBJM, Sussenbach IS. Complete nucleotide sequence of the high molecular weight human IGF-I mRNA. Biochem Biophys Res Commun 1991;175:507-14

14 de Pagter-Holthuizen P, Jansen M, van der Kammen RA, van Schaik FMA, Sussenbach JS. Differential expression of the human insulin-like growth factor II gene. Characterization of the IGF-II mRNAs and an mRNA encoding a putative IGF-II associated potein. Biochim Biophys Acta 1988;950:282 95.

15 Clemmons DR. IGF binding proteins: regulation of cellular actions. Growth Regul 1992;2:80-87.

16 Oberbäumer I. Retroposons do jump: a B2 element recently integrated in an 18S rDNA gene. Nucleic Acids Res 1992;20:671-7.

17 Brinkman A, Groffen C, Kortleve DJ, Geurts van Kessel A, Drop SLS. Isolation and characterization of a cDNA encoding the low molecular weight insulin-like growth factor binding protein (IBP1). $E M B O J$ 1988;7:2417-23.

18 Delhanty PJD, Han VKM. The characterization and expression of ovine insulin-like growth factor-binding protein-2. J Mol Endocrinol 1992;9:31-8.

19 Shimasaki S, Shimonaka M, Ui M, Inouye S, Shibata F, Ling N Structural characterization of a follicle-stimulating hormone action inhibitor in porcine ovarian follicular fluid. $J$ Biol Chem 1990;265:2198-202.

20 Kiefer MC, Masiarz FR, Bauer DM, Zapf J. Identification and molecular cloning of two new 30-kDa insulin-like growth factor binding proteins isolated from adult human serum. I Biol Chem 1991;266:9043-9.

21 Kiefer MC, Ioh RS, Bauer DM, Zapf J. Molecular cloning of a new human insulin-like growth factor binding protein. Biochem Biophys Res Commun 1991;176:219-25.

22 Chomzynski P, Sacchi N. Single step method of RNA isolation by acid guanidinium thiocyanate-phenol-chloroform extraction. Anal Biochem 1987:162:156-9.

23 Sambrook J, Fritsch EF, Maniatis T. Molecular cloning: a laboratory manual. (2nd ed.) Cold Spring Harbor: Cold Spring Harbor Laboratory Press, 1989.

24 Shimasaki S, Ling N. Identification and molecular characterization of insulin-like growth factor binding proteins (IGFBP-1, -2, -3, -4, -5, and -6). Prog Growth Factor Res 1991;3:143-266.

25 Boulle N, Schneid H, Listrat A, Holthuizen P, Binoux M, Groyer A. Developmental regulation of bovine insulin-like growth factor-II (IGF-II) gene expression: homology between bovine transcripts and human IǴF-II exons. J Mol Endocrinol 1993;11:117-28.

26 Engelmann GL, Boehm KD, Haskell JF, Khairallah PA, Ilan J. Insulin-like growth factors and neonatal cardiomyocyte development: ventricular gene expression and membrane receptor variations in normotensive and hypertensive rats. Mol Cell Endocrinol 1989:63:1-14

27 Kern PA, Svoboda ME, Eckel RH, Van Wyk JJ. Insulin-like growth factor action and production in adipocytes and endothelial cells from human adipose tissue. Diabetes 1989;38:710-7. 
28 Gloudemans T, Pospiech I, Vanderven LTM, et al. Expression and $\mathrm{CpG}$ methylation of the insulin-like growth factor-II gene in human smooth muscle tumors. Cancer Res 1992;52:6516-21.

29 Gartner MH, Benson JD, Caldwell MD. Insulin-like growth factors I and II expression in the healing wound. J Surg Res 1992:52:389-94.

30 Froesch ER, Schmid C, Schwander J, Zapf J. Action of insulinlike growth factors. Annu Rev Physiol 1985;47:443-67.

31 Pollack PS, Houser SR, Budjak R, Goldman B. c-myc Gene expression is localized to the myocyte following haemodynamic overload in vivo. J Cell Biochem 1994;54:78-84.

32 Marber MS, Latchman DS, Walker JM, Yellon DM. Cardiac stress protein elevation 24 hours after brief ischemia or heat stress is associated with resistance to myocardial infarction. Circ Res 1993;88:1264-72.

33 Yellon DM, Latchman DS. Stress proteins and myocardial protection. J Mol Cell Cardiol 1992;24:113-24.

34 Ewton DZ, Falen SL, Florini JR. The type II insulin-like growth factor (IGF) receptor has low affinity for IGF-1 analogs: pleiotropic actions of IGFs on myoblasts are apparently mediated by the type I receptor. Endocrinology 1987;120:115-23.

35 Leaman DW, Simmen FA. Insulin-like growth factor-I and II messenger RNA expression in muscle, heart, and liver of streptozotocin-diabetic swine. Endocrinology 1990;126:2850-7.

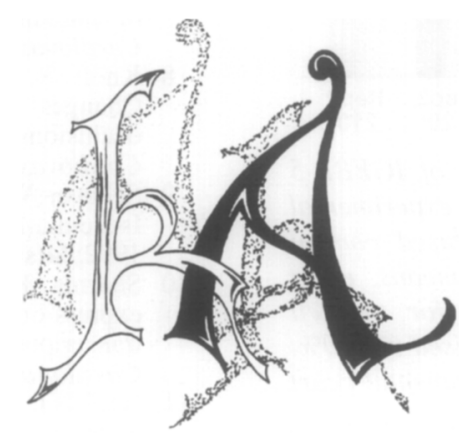

